\author{
AMERICAN JOURNAL OF FOOD AND NUTRITION \\ Print: ISSN 2157-0167, Online: ISSN 2157-1317, doi:10.5251/ajfn.2013.3.3.127.134 \\ C 2013, ScienceHu $\beta$, http://www.scihub.org/AJFN
}

\title{
Nutritional and sensory properties of cashew nut-wheat based cookies
}

\author{
Ojinnaka, M.C and Agubolum, F.U \\ Department of Food Science and Technology \\ Imo State University, Owerri \\ PMB 2000, Owerri, Imo State, Nigeria. \\ ABSTRACT
}

\begin{abstract}
The effect of substitution of wheat flour with cashew nut paste in cookie production was investigated. The cashew nut paste obtained was used at different levels of substitution with wheat flour for cookie production. The proximate compositions of cookies were determined using standard methods. The result of the proximate analysis showed the protein content of the cookie samples ranged from $7.76-11.84 \%$, moisture content $3.11-5.13 \%$, fat content $16.41-44.34 \%$, crude fibre $0.46-1.24 \%$, ash content $1.82-5.95 \%$ and carbohydrate $34.30-68.00 \%$. The antinutritional factors determined (tannin, phytate, alkaloid, phenol and hydrogen cyanide) in the cookies showed they all had low values which are not detrimental to the health of consumers. The sensory evaluation results of the cookie samples showed they were liked by the panelist. $100 \%$ wheat flour cookie was used as the standard for comparison.
\end{abstract}

Key words: cashew nut, wheat flour, cookies

\section{INTRODUCTION}

Cashew nut (Anarcadium occidentale) is a heart like shaped fruit widely grown in Africa and West Indies. The cashew tree is a native of Brazil and this is a valuable cash crop in the Americans, West Indies, Madagascar India and Malaysian (Frankel, 1991). The major producing countries of cashew are Tanzania, India, Mozambique, Sri Lanka, Kenya, Madagascar, Thailand, Malaysia, Nigeria, Malawi and Angola. World Bank data estimates that $97 \%$ of production is from wild trees and only $3 \%$ is from established plantation (Rosengarten, 1984). In Nigeria, about 5000-7000 tones are produced annually mainly as an export crop (Aremu et al., 2006). Africa is the third largest global source of cashew nut and produces about 100,000 tones per year (Spare 1997). Trends in production of cashew are also related to consumption and these in turn will depend on the world economic situation.

Flours milled from other crops such as maize, millet, sorghum, cassava, potatoes and rice had been added to wheat flour to extend the use of the local crops and reduce the cost of wheat importation. This is practiced mostly in tropical countries where the soil and climate are not favourable for commercial large scale production of wheat. Nigeria has not been able to produce wheat in commercial quantities because of climatic and soil conditions. This means that nearly all the wheat for bread, cookies and other products are imported. An alternative local substitute for wheat flour will reduce expenditure on wheat flour importation thereby encouraging the use of composite flour in snack products (Olatunji, 1986). Also in selecting the components to be used in composite flour blends, the materials should preferably be readily available, culturally acceptable and provide increased nutritional potential ( Akobundu et al., 1998).

Cookies have been suggested as a better use of composite flour than bread due to their ready- to -eat form, wide consumption, relatively long shelf life and good eating quality (Okpala and Chinyelu, 2011). Cookies with high sensory ratings have been produced from blends of wheat and some underutilized plant species. Cookie production using cashew nut paste will help to increase the nutritional value of cashew nut-wheat based products as well as help to reduce the importation rate of wheat into the country. This study however was carried out to determine the potential of cashew nut paste and wheat flour blends in cookie production.

\section{MATERIALS AND METHODS}

Raw Material Sources: Unroasted cashew nuts were purchased from Okwudo market, Okwudo in Imo State. Food ingredients purchased include wheat flour, sugar, salt, margarine, eggs and baking powder. Also reagents used for the chemical analysis were of analytical grade.

Cashew Nut Processing: The unroasted cashew nuts were sorted to remove the stones, dirts and unwholesome cashew nuts. The nuts were soaked in 
water for two minutes and sun dried ready for roasting. The nuts were roasted for fifteen minutes using the open pan roasting method. The wood hammer was used for manual shelling of the nuts. The roasted cashew nuts were oven dried and the peels or covering tasta were removed by squeezing and then winnowed to obtain the cream coloured cashew nuts. After grading, the roasted cashew nuts were packaged in an airtight container and kept at room temperature.

Table 1. Blend formulation of the cookie samples
Production Of Cookies Using Wheat Flour And Cashew Nut Paste : The cookies were prepared using the cream -in method (Asomugha and Uwalaka, 2000). One hundred percent wheat flour was used as the control. Cookies were produced using cashew nut paste at different substitution level with wheat flour using the proportion stated below:

\begin{tabular}{|l|l|c|c|c|c|}
\hline & Sample A & Sample B & Sample C & Sample D & Sample E \\
\hline Wheat flour (\%) & $90 \%$ & $80 \%$ & $70 \%$ & $60 \%$ & $100 \%$ \\
\hline Cashew nut paste (\%) & $10 \%$ & $20 \%$ & $30 \%$ & $40 \%$ & - \\
\hline
\end{tabular}

Proximate Analysis Of Cashew Nut-Wheat Based Cookies: The proximate analysis of the cookie samples were done using the method of AOAC (2000).

\section{Determination Of Antinutritional Factors}

Determination of tannin: Tannin content of the sample was determined Folin Denis Colometric method (Kirk and Sawyer 1998). A measured weight of the processed sample $(5.0 \mathrm{~g})$ was mixed with distilled water in the ration of $1: 10(\mathrm{w} / \mathrm{v})$. The mixture was shaken for 30 minutes at room temperature fittered to obtain the extract.

A standard tannic acid solution was prepared, $2 \mathrm{ml}$ of the standard solution and equal volume of distilled water were dispersed into a separate $50 \mathrm{ml}$ volumetric flask to serve as standard and reagent blank respectively. Then $2 \mathrm{mls}$ of each of the sample extract was put in their respective lapelled flask.

The content of each flask was mixed with $35 \mathrm{ml}$ distilled water and $1 \mathrm{ml}$ of the Folin Denis reagent was added to each. This was followed by $2.5 \mathrm{mls}$ of saturated $\mathrm{Na}_{2} \mathrm{CO}_{3}$ solution. There after each flask was diluted to the $50 \mathrm{ml}$ mark with distilled water and incubated for 90 minutes at room temperature. Their absorbance was measured at $760 \mathrm{~nm}$ in a spectrophotometer with the reagent blank at zero. The tannin content was calculated as show below:

$$
\begin{aligned}
\% \text { tannin } & =\frac{100}{\mathrm{~W}} \times \frac{\mathrm{au}}{\mathrm{as}} \times \mathrm{c} \times \frac{\mathrm{V}}{\mathrm{Va}} \\
\mathrm{W} & =\text { weight of sample } \\
\mathrm{Au} & =\quad \text { absorbance of test sample }
\end{aligned}
$$

As $=$ absorbance of test sample

$\mathrm{C}=$ concentration of standard

tannin solution

$\mathrm{Vt}=$ total volume of extract

$\mathrm{Va}=$ volume of extract analyzed

Determination of saponin: This was done by the double solvent extraction gravimetric method (Harborne, 1973). $5.0 \mathrm{~g}$ of the processed sample was mixed with $50 \mathrm{~m} / \mathrm{s}$ of $20 \%$ aqueous ethanol solution and incubated for 12 hours at temperature of $55^{\circ} \mathrm{C}$ with constant agitation. After that, the mixture was fittered through Whitman N0 42 grades of fitter paper. The residue was re-extracted with $50 \mathrm{ml}$ of the ethanol solution for 30 minutes and the extracts weighed together. The combine extract was reduced to about $40 \mathrm{mls}$ by evaporation and the transferred to a separating funnel and equal volume $(40 \mathrm{~m} / \mathrm{s})$ of diethyl ether was added to it. After mixing well, there was partition and the other layer was discarded while the aqueous layer was reserved. This aqueous layer was re-extracted with the ether after which its $\mathrm{PH}$ was reduced to 4.5 with dropwise addition of dilute $\mathrm{NaOH}$ solution. Saponin in the extract was taken up in successive extraction with $60 \mathrm{ml}$ and $30 \mathrm{ml}$ portion of named butanol. The combine entrant (ppt) was washed with $5 \% \mathrm{NaCl}$ solution and evaporated to dryness in a previously weighed evaporation dish. The saponin was then dried in the oven at $60^{\circ} \mathrm{C}$ (to remove any residual solvent) cooled in a desicctaor and re-weighed. The saponin content was calculated as shown below:

$\%$ saponin $=\underline{W 2-W 1}$

W 


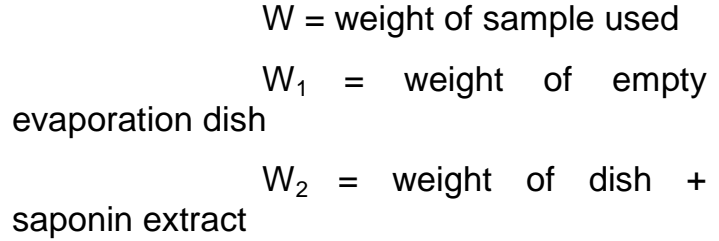

Determination of alkaloid: The alkaline precipitation gravimetric method (Harborne 1973) was used.

A measured weight of the processed sample $(5 \mathrm{~g})$ was dispersed in $100 \mathrm{mls}$ of $10 \%$ acetic in ethanol solution. The mixture was shaken well and allowed to stand for 4 hours at room temperature being shaken every 30minutes. At the end of this period, the mixture was filtered through whatman NO 42 grade of fitter paper.

The filtrate (Extract) was concentrated by evaporation to a quarter of its original volume the extract was treated with dropwise addition of concentrated $\mathrm{NH}_{3}$ solution to precipitate the alkaloid. The dilution was done until the $\mathrm{NH}_{3}$ was in excess.

The alkaloid precipitate was removed by filtration using weighed whatman No 42 filter paper. After washing with $1 \% \mathrm{NH}_{4} \mathrm{OH}$ solution, the precipitate in the filter paper was dried at $60^{\circ} \mathrm{C}$ and weighed after cooling in a desiccator. The alkaloid content was calculated as shown below.

$$
\% \text { Alkaloid }=\underline{W}_{2}-\underline{W}_{1} \quad \times \quad \underline{100}
$$

Where $W_{1}=$ Weight of empty filter paper

$$
\mathrm{W}_{2}=\text { weight of filter paper +alkaloid ppt }
$$

Determination of phenol: This was determined by the Folin- ciocateam spectrophotometer (AOAC 1990). The total phenol was extracted in $200 \mathrm{mg}$ of the sample with $10 \mathrm{ml}$ concentrated methanol. The mixture was shaken for 30 minutes at room temperature. The mixture was centrifuged at 500rpm for 15 minutes and the supernatant (extract) was used for the analysis. $1 \mathrm{ml}$ portion of the extract from each sample was treated with equal volume of folinciocalteau regent followed by the addition of $2 \mathrm{~m} / \mathrm{s}$ of $2 \% \mathrm{Na}_{2} \mathrm{CO}_{3}$ solution. Meanwhile, standard phenol solution was prepared and diluted to desired concentration. $1 \mathrm{ml}$ of the standard solution was also treated with the F-D reagent and $\mathrm{Na}_{2} \mathrm{Co}_{3}$ solution. The intensity of the resulting blue colouration was measured (absorbance) in a spectrophotometer at $560 \mathrm{~nm}$ wavelength. Measurement was made with a reagent blank at zero. The phenol content was calculated using the formula below:

$$
\begin{aligned}
& \% \text { phenol }=\frac{100}{\mathrm{~W}} \times \frac{\mathrm{au}}{\mathrm{W}} \times \mathrm{CS} \times \underline{\mathrm{Vt}} \mathrm{Va} \\
& \text { Where } \mathrm{W}=\text { weight of sample } \\
& \mathrm{Au}=\text { absorbance of test sample } \\
& \mathrm{As}=\text { absorbance of standard phenol sample } \\
& \mathrm{C}=\text { concentration of standard phenol sample } \\
& \mathrm{Vt}=\text { total extract volume } \\
& \mathrm{Va}=\text { volume of extract analyzed }
\end{aligned}
$$

Determination of hydrogen cyanide (HCN): This was determniated by alkaline Pikrate colorimeter method by Balogopalan et al (1988). $1.02 \mathrm{~g}$ of this sample was dispersed in $50 \mathrm{ml}$ of distilled water in a $25.0 \mathrm{ml}$ conical flask. An alkaline Pikrate paper was hung over the sample mixture and the blank in their respective flasks. The set up were incubated overnight and each Pikrate paper was eluted (or dipped) into a $60 \mathrm{ml}$ of edistilled water. A standard cyanide solution was prepared and diluted to a required concentration. The absorbances of the eluted sample solution of the standard were mea red spectophotometrically at $540 \mathrm{~nm}$ wavelength with the reagent blank at zero.

The cyanide content was determined by the formular shown below:

$$
\begin{aligned}
& \mathrm{HCN} \mathrm{mg/kg}=\frac{1000}{\mathrm{~W}} \times \frac{\mathrm{au}}{\mathrm{as}} \times \frac{\mathrm{CxD}}{1} \\
& \text { Where } \mathrm{W}=\text { weight of sample analyzed } \\
& \mathrm{Au}=\text { absorbance of test sample } \\
& \mathrm{As}=\text { absorbance of standard } \mathrm{HCN} \text { solution } \\
& \mathrm{C}=\text { concentration of the standard in } \mathrm{mg} / \mathrm{dl} \\
& \mathrm{d}=\text { dilution factor where applicable. }
\end{aligned}
$$

Determination of flavonoids: Flavonoid was determined using the method described by Harbone (1973). A measurement weight processed sample $(5 \mathrm{~g})$ was reflux for 40 minutes. It was allowed to cool before being filtered. The filterate was treated with equal volume of ethyl acetate and the moisture was transferred to a separation funnel. The flavoniod extract (contained in the ethyl acetate portion) was received by filteration using weight fitter paper. The weight was obtained sfter drying in the oven and cooling in a desiccator. The weight was expressed as percentage of weight analysed. It was calculated as shown below:

$$
\% \text { flavonoid }=\frac{W_{2}}{W_{t}}-\frac{W_{1}}{\text { of sample }} \times \frac{100}{1}
$$




\author{
precipitate \\ $\mathrm{W}_{2}=$ weight of filter paper $\mathrm{x}$ flavonoid \\ $W_{1}=$ weight of filter paper alone.
}

Sensory evaluation: The sensory evaluation was performed using the method of Iwe (2002). A 15 man panel made up of students and staff of Imo state university were used for the sensory evaluation of the cookies. The cookies were evaluated by panelists for taste, appearance, texture, flavour and general acceptability. The scoring was based on a 9 point hedonic scale ranging from 9 (extremely like) to 1 (extremely dislike) and 5 (neither like nor dislike).

Statistical analysis: All the values obtained from the proximate analysis; antinutritional factors and organoleptic evaluation of the cashew nut wheatbased cookies where statistical analyzed using one factor randomized design ANOVA as described by OMahoney (1986).

\section{RESULTS AND DISCUSSION}

Proximate Composition Of Cookies Produced From Cashew Nut Paste And Wheat Flour: The protein content of the cookie samples were significantly different. Sample E $(100 \%$ wheat flour cookie) had the highest mean percentage protein content of 11 . $84 \%$ while the least value was recorded for sample $A(90: 10)$ with percentage mean value of $7.76 \%$. The result implies that the cookie samples were high in protein content and could be used as alternative protein source in protein deficiency. The protein content of the cookies ranged from $7.76-11.84 \%$. The protein content of cashew nuts has been reported to be 13.13-25.03\% in various regions of India (Nandi, 1998). It has been suggested that protein content be considered as one of the most important factors in future breeding and selection programs of cashew nuts.

Sample A $(90: 10)$ was significantly higher $(p<0.05)$ in terms of moisture content. It has the highest percentage moisture content of $5.13 \%$ while the least value was recorded for sample E (60: 40) with of $3.11 \%$. The moisture content range was within 3.11 $5.13 \%$. These values were minimal and may not have adverse effect on the quality attributes of the product (Kure et al., 1998).The low moisture content values observed in this study will also increase the shelf life of the product. Wade and Staffor (1968), reported that the moisture content of different biscuits vary according to the type of biscuit produced, cream crackers has about $4.3 \%$ moisture content while digestive has about $4.5 \%$.
There was significant difference $(p<0.05)$ in the fat content of the cookie samples. Sample E (100.0) which served as the control had the highest value of $44.34 \%$ while the least value was recorded for sample A (90:10) with $16.41 \%$. The fat content values ranged from $16.41-44.34 \%$. The fat and oil content of cashew nut contributes substantially to its energy content (Ohler, 1979). Wade and Staffor (1968) have reported $20.5 \%$ fat content in digestive biscuits. Fat plays a significant role in determining the shelf life of food products and as such relatively high fat content could be undesirable in baked food products. This is because fat can promote rancidity in food, leading to development of unpleasant and odorous compounds (Ihekoronye and Ngoddy, 1985). Also diet high in fat predisposes consumers to different illnesses such as obesity, coronary heart diseases (Okpala and Chinyelu, 2011). The was no significant difference ( $p$ $<0.05)$ in the fibre content of the samples. Sample D $(60: 40)$ had the highest mean score of $1.24 \%$ while the least was recorded in sample $E(100: 0)$ with the value of $0.46 \%$. Crude fibre is known to aid the digestive system of human (Ihekoronye and Ngoddy, 1985).

The was significant difference $(p<0.05)$ in the ash content of the cookie samples. Sample E (100:0) had the highest mean value of $5.95 \%$ while the least mean value was recorded in sample A (90:10) with $1.82 \%$. The result shows that the samples are low in ash content except sample E (100:0) the control which had the value of $5.95 \%$. Ash is a non- organic compound containing mineral content of food and nutritionally it aids in the metabolism of other organic compounds such as fat and carbohydrate (Mcwilliam, 1978).

Sample A $(90: 10)$ was significantly higher $(p<0.05)$ with $68.00 \%$ in the carbohydrate content while the least value was recorded in sample $E$ with $34.30 \%$ which implies that the cookies are rich carbohydrate source. According to Messiaen (1992), the higher the protein fat, ash content, the less the carbohydrate. Similar results have been reported by Chikwendu (2007) and Yusuf et al., (2008). Biscuit is an energy food which is taken mostly in between meals by both young and old (Giwa and Abiodun, 2010). 
Am. J. Food. Nutr, 2013, 3(3): 127-134

Table 2. Proximate composition of cookies produced from cashew nut paste and wheat flour (\%)

\begin{tabular}{|c|c|c|c|c|c|}
\hline Sample/parameter & $\mathbf{A}$ & B & $\mathbf{C}$ & D & $\mathbf{E}$ \\
\hline Moisture content & $5.13^{a} \pm 0.07$ & $4.53^{b} \pm 0.04$ & $4.37^{b}+0.03$ & $4.42^{a} \pm 0.09$ & $3.11^{a} \pm 0.05$ \\
\hline Protein & $7.76^{\mathrm{e}} \pm 0.01$ & $9.68^{d} \pm 0.20$ & $10.15^{c}+0.35$ & $10.91^{\bar{b}}+0.10$ & $11.84^{\bar{a}}+0.10$ \\
\hline Fat & $16.41^{\mathrm{e}} \pm 1.73$ & $24.23^{b} \pm 0.06$ & $27.21^{\mathrm{c}}+0.03$ & $29.81^{b}+0.39$ & $24.34^{a}+0.03$ \\
\hline Carbohydrate & $68.00^{a} \pm$ & $58.20^{b}+0.23$ & $54.70^{c}+0.43$ & $50.88^{d}+0.38$ & $34.30^{\mathrm{e}}+0.07$ \\
\hline Fibre & $0.88^{a} \pm 0.01$ & $1.16^{\mathrm{a}}+\overline{0} .02$ & $1.22^{\mathrm{a}}+0.02$ & $1.24^{\mathrm{a}}+0.01$ & $0.46^{\mathrm{a}}+0.02$ \\
\hline Ash & $1.82^{\mathrm{e}} \pm 0.02$ & $2.19^{\mathrm{cd}} \pm 0.02$ & $2.35^{c}+0.04$ & $2.73^{b}+0.22$ & $5.95^{a}+0.03$ \\
\hline
\end{tabular}

${ }^{*}$ Means in the same row with the same superscript are not significantly different at $p<0.05$. where
A $=$
$90 \%$ wheat flour +
$10 \%$ of cashewnut paste
$\mathrm{B}=$
$80 \%$ wheat flour +
$70 \%$ wheat flour +
$20 \%$ of cashewnut paste
$30 \%$ of cashewnut paste
$\begin{array}{lll}\mathrm{C} & = & 60 \% \text { wheat flour }+ \\ \mathrm{E} & = & 100 \% \text { wheat control. }\end{array}$
$40 \%$ of cashewnut paste 
Anti-Nutritional Factors In Cashew Nut - Wheat Based Cookies: All the values obtained appeared to be low and in reasonable agreement with those reported by commonly consumed food article (Ezeagu, 2005). Low levels of anti- nutritional factors such as tannins, saponins, phytate, and hydrogen cyanide have been reported in cookies produced from pigeon pea, cocoyam and sorghum flour blends (Okpala and Okoli, 2011). The saponin content of the cashew nut-wheat based cookies were very low suggesting that in this regard, they pose no threat to human consumption. Okpala and Chinyelu (2011) reported similar findings in cookies produced from pigeon pea and cocoyam flour blends. Saponin has been reported to lower plasma cholesterol concentration (Topping et al., 1980). The low level of saponins in the cookies could be due to leaching when the cashew nuts were soaked. Low levels of tannin were also observed in the cookie samples. Onwuka (2005) reported that the presence of tannins can cause browning or other pigmentation problems in both fresh food and processed products. He also stated that tannins can provoke an astringent reaction in the mouth and make the food unpalatable and that they can complex with and thus precipitates proteins in the gut, reducing the digestibility or inhibiting digestive enzymes and micro organisms.

Table 3. Result of Antinutritional factors in cookies produced from cashew nut paste and wheat flour

\begin{tabular}{|l|l|l|l|l|l|}
\hline Sample/parameter & $\mathbf{A}$ & $\mathbf{B}$ & $\mathbf{C}$ & $\mathbf{D}$ & $\mathbf{E}$ \\
\hline Tannin & $0.09^{\mathrm{a}} \pm 0.00$ & $0.10^{\mathrm{a}}+0.00$ & $0.14^{\mathrm{a}} \pm 0.01$ & $0.11^{\mathrm{a}} \pm 0.08$ & $0.21^{\mathrm{a}} \pm 0.03$ \\
\hline Saponin & $0.11^{\mathrm{a}} \pm 0.01$ & $0.11^{\mathrm{a}} \pm 0.01$ & $0.09^{\mathrm{a}} \pm 0.01$ & $0.09^{\mathrm{a}} \pm 0.01$ & $0.07^{\mathrm{a}} \pm 0.0$ \\
\hline$\%$ Alk & $0.05^{\mathrm{a}} \pm 0.01$ & $0.09^{\mathrm{a}} \pm 0.02$ & $0.13^{\mathrm{a}} \pm 0.01$ & $0.15^{\mathrm{a}} \pm 0.01$ & $0.25^{\mathrm{a}} \pm 0.01$ \\
\hline$\%$ Phenol & $0.04^{\mathrm{a}} \pm 0.00$ & $0.04^{\mathrm{a}} \pm 0.00$ & $0.05^{\mathrm{a}} \pm 0.00$ & $0.05^{\mathrm{a}} \pm 0.00$ & $0.13^{\mathrm{a}} \pm 0.00$ \\
\hline$\%$ Phytate & $0.06^{\mathrm{a}} \pm 0.00$ & $0.07^{\mathrm{a}} \pm 0.00$ & $0.08^{\mathrm{a}} \pm 0.00$ & $0.08^{\mathrm{a}} \pm 0.00$ & $0.18^{\mathrm{a}} \pm 0.00$ \\
\hline$\%$ HCN & $1.40^{\mathrm{a}} \pm 0.03$ & $1.44^{\mathrm{a}} \pm 0.05$ & $1.53^{\mathrm{a}} \pm 0.03$ & $1.68^{\mathrm{a}} \pm 0.03$ & $0.42^{\mathrm{a}} \pm 0.03$ \\
\hline
\end{tabular}

${ }^{*}$ Means in the same row with the same superscript are not significantly different at $p<0.05$.

$A=90 \%$ wheat flour $+10 \%$ of cashew nut paste

$\mathrm{B}=80 \%$ wheat flour $+20 \%$ of cashew nut paste

$\mathrm{C}=70 \%$ wheat flour $+30 \%$ of cashew nut paste

$\mathrm{D}=60 \%$ wheat flour $+40 \%$ of cashew nut paste

$E=100 \%$ wheat control.

Sensory evaluation of cookie samples: There was no significant difference $(p<0.05)$ in the appearance of the cookies though sample $C(70: 30)$ had the highest mean score of $6.0 \%$ while the least mean score was recorded in sample D $(60: 40)$ with $5.33 \%$. The values which ranged from $5.3-6.0 \%$ translate to slightly liked and like moderately in the hedonic scale used for the organoleptic analysis of the cookie samples. The result implies that sample $C$ with mean value of $6.0 \%$ is the most preferred in appearance by the judges. Colour is a very important parameter in judging properly baked biscuits that not only reflect the suitable raw material used for the preparation but also provides information about the formulation and quality of the product (Abu-salem and Abou- Arab, 2011).
There was significant difference $(p<0.05)$ in terms of crispiness of the cookies. Sample $C(70: 30)$ had the highest mean score of $6.13 \%$ while the least value was recorded in sample A $(90: 10)$ with value of $4.53 \%$. The result indicates that sample $C(70: 30)$ is the most preferred in terms of crispness. The value ranged from 4.53-6.13 which translates to like slightly and like moderately in the hedonic scale. There was no significant difference $(p<0.05)$ in the taste of the cookies. Sample E (100\% wheat) had the highest mean score of $5.87 \%$ while the least was recorded in sample D (60: 40 ) with $5.00 \%$. The sense of taste provide to its ingestion and uptake into the body (Iwe, 2007). There was also no significant difference $(p<$ $0.05)$ in the aroma of the cookies. Sample C (70:30) had the highest mean score of $5.60 \%$. while the least mean score was recorded in sample D (60:40) with $5.00 \%$. The result indicates that cookie sample C $(70: 30)$ is the most preferred in terms of aroma. Flavour is the main criteria that makes the product to be liked or disliked (Abu-Salem and Abou-Arab, 2011). The sensations of taste and smell are functions of flavour which is a complex of sensations (Iwe, 2007). Food flavour according to Ihekoronye 
and Ngoddy (1985) arises from a subtle interaction of taste and aroma, which imparts a pleasing and displeasing sensory experience to a consumer. It is the flavour of a food that ultimately determines its acceptance or rejection, even though its appearance evokes the initial response.

There was significant difference $(p<0.05)$ in the overall acceptability of the cookies

Sample E (100\% wheat flour) had the highest score of $6.40 \%$ followed closely by sample C (70:30) with
$5.80 \%$ while the least value was recorded in sample D $(60: 40)$ with $4.93 \%$. The result of the sensory evaluation of the cookies are similar to the finding of Gambus et al., (2003) who reported increasing the levels of flax seed flour, matric flour, cowpea flour in the cookies resulted in significant decrease in the sensory attributes of the biscuits. Similar findings were also made by Abu-Salem and AbouArab,(2011).

Table 4. Mean sensory scores of cashew nut- wheat based cookies (\%)

\begin{tabular}{|l|l|l|l|l|l|l|}
\hline Sample/parameter & $\mathbf{A}$ & $\mathbf{B}$ & $\mathbf{C}$ & $\mathbf{D}$ & $\mathbf{E}$ & LSD \\
\hline Appearance/ colour & $5.6^{\mathrm{a}} \pm 2.06$ & $5.53^{\mathrm{a}} \pm 1.51$ & $6.0^{\mathrm{a}} \pm 0.93$ & $5.33^{\mathrm{a}} \pm 0.72$ & $5.8^{\mathrm{a}} \pm 1.15$ & - \\
\hline Crispiness/ texture & $4.53^{\mathrm{c}} \pm 1.10$ & $5.40^{\mathrm{ab}} \pm 1.24$ & $6.13^{\mathrm{a}} \pm 1.19$ & $5.00^{\mathrm{bc}} \pm 1.07$ & $5.93^{\mathrm{bc}} \pm 1.03$ & 0.78 \\
\hline Taste & $5.13^{\mathrm{a}} \pm 2.10$ & $5.27^{\mathrm{a}} \pm 1.62$ & $5.60^{\mathrm{a}} \pm 1.24$ & $5.00^{\mathrm{a}} \pm 1.31$ & $5.87^{\mathrm{a}} \pm 0.92$ & - \\
\hline Aroma/flavour & $5.13^{\mathrm{a}} \pm 1.85$ & $5.13^{\mathrm{a}} \pm 0.92$ & $5.60^{\mathrm{a}} \pm 1.35$ & $5.00^{\mathrm{a}} \pm 1.00$ & $5.4^{\mathrm{a}} \pm 0.99$ & - \\
\hline Overall/acceptability & $5.47^{\mathrm{bc}} \pm 1.85$ & $5.0^{\mathrm{bc}} \pm 1.56$ & $5.8^{\mathrm{ab}} \pm 1.52$ & $4.93^{\mathrm{c}} \pm 1.39$ & $6.4^{\mathrm{a}} \pm 2.38$ & 0.85 \\
\hline
\end{tabular}

*Means in the same row with the same superscript are not significantly different at $p<0.05$.

$\mathrm{A}=90 \%$ wheat flour $+10 \%$ of cashew nut paste

$B=80 \%$ wheat flour $+20 \%$ of cashew nut paste

$\mathrm{C}=70 \%$ wheat flour $+30 \%$ of cashew nut paste

$D=60 \%$ wheat flour $+40 \%$ of cashew nut paste

$E=100 \%$ wheat control.

\section{CONCLUSION}

The effect of blend proportion on the quality of cookies made from cashew nut and wheat flour will help reduce the importation cost of wheat flour in Nigeria. This research study indicates that cookies produced from cashew nut paste and wheat flour contain sufficient percentage of protein, fat and carbohydrate. Sample C (70:30) was most preferred by the members of the panel. The judicious use of cashew nut paste in the diet in suitable proportions to enhance dietary quality with respect to fat and protein should therefore be encouraged. Owing to its high protein content, it could be used along with cereals/staples and pulses in small amounts in association with vegetables to improve the dietary profile.

\section{REFERENCE}

Abu-Salem, F.M. and Abou-Arab, A.A. (2011). Effect of supplementation of Bambara groundnut (Vigna subterranean L.) flour on the quality of biscuits. Afr. J. Food Sci. 5(7):376-383

AOAC (1990). Official Methods of Analysis. Assn. of Official Anal. Chemists, Washington, D.C.

AOAC. (2000). Association of Official Analytical Chemists. Official methods of Analysis (Vol. II $17^{\text {th }}$ edition) of AOAC International. Washington, DC, USA.

Akobundu ENT, Ubbaonu CN and CE Ndupuh (1998). Studies on the baking potential of on-wheat composite flours. J. Food Sci. Tech. 1998; 25:211-214.

Aremu, M.O., A. Olonisakin DA. Bako and P.C. Made 2006. Compositional Studies and Physicochemical Characteristics of Cashew Nut (Anarcdium occidentale) Flour. Pak. Nutry 5: 328-33

Asumugha, V.U. and Uwalaka, B.C. (2000). Chemical and organoleptic evaluation of snacks developed from cocoyam (Colocasia esculenta, Xanthosoma mafafa) and wheat (Triticum spp) composite flours. Nigeria Agricultural Journal. 31, 78-88

Balogopalan,C., Padmola, G., Nanda, S.K. and Moorthy, S.N. (1988). Cassava in food and feed industry. CRC Press, Boca Raton, FI., USA. Pp.13

Chikwendu, N.J. (2007). Chemical composition of four verities of ground bean (Kerstingiella geocarpa). J. Agric. Food Environ. Ext., 6(2): 73-64.

Ezeagu, I.E. (2005). Baobab (Adansonia digitata) seed protein utilization in young albino rats I: Biochemical 
ingredients and performance characteristics. Anim. Res. Int. 2(1): 240-245.

Frankel, E. (1991). Poison ivy, Poison oak, Poison sumac and their relative pistachios: Mangoes and Cashew. The Boxwood Press pacific Grove CA 2, 15-16

Gambus H, Milulec A, Matusz A (2003). The Canadian muffins and hermit cookies with linseeds. Zywnosc, 10(3): 82-92

Giwa, E.O. Abiodun, I.V (2010). Quality characteristics of biscuits produced from composite flours of wheat and quality protein maize. Afr. J. Food Sci. 1 (5): 116-119

Harborne, J.B (1973). Phytochemical Methods. Chapman and Hall Ltd., London pp. 49-188.

Ihekoronye Al, Ngoddy PO (1985). Integrated food science and technology for the tropics. 1st ed. McMillan publishers. pp. 261- 291.

Iwe, M.O (2002). Handbook of Sensory methods and analysis. Rojoint Com. Services Ltd. Enugu, Nigeria

Iwe, M.O. (2007). Current trends in sensory evaluation of foods. Rojoint comm. Services Ltd, Enugu. P 46-47.

Kirk, R. and Sawyer, R.(1998). Pearson's composition and analysis of foods. Church Hill Livingstone, dinbburgh.

Kure OA, Bahago EJ, Daniel EA (1998). Studies on the Proximate Composition and Effect of Flour Particle Size on Acceptability of Biscuit Produced from Blends of Soyabeans and Plantain flours. Namida Tech-Scope J. 3: 17-21.

Mcwillien, M. (1978). Food fundamental $3^{\text {rd }}$ edition. California State University Los Angeles. P .27-29.

Messiaen, C. M. (1992). The tropical vegetable garden. Maemillian Itd. London and Basing stoke. P 218-247.

Nandi, B.K. (1998). Cashew nut: nutritional aspects. In: Integrated production practices of cashew in Asia and the Pacifics. Bangkok, Thailand. Papademetriou, M.K. and E.M. Herath (Eds.), pp:74-80
O'Mahony, M. (1986). Sensory Evaluation of Food: Statistical Methods and Procedures. Marcel Dekker, Inc, New York. Pg 8-209.

Ohler, J.G. (1979). Cashew. Department of Agricultural Research, Royal Tropical Institute, Amsterdam.

Okpala, L.C. and Okoli, E.C. (2011). Nutritional evaluation of cookies produced from pigeon pea, cocoyam and sorghum flour blends. Afr. J. Biotechnol. 10(3):433438

Okpala, L.C. and Chinyelu, V.A (2011). Physicochemical, Nutritional and Organoleptic evaluation of cookies form pigeon pea (Cajanus cajain) and cocoyam (Xanthosoma sp) flour blends. AJFAND 11(6):54315443

Onwuka, G.T (2005). Food Analysis and Instrumentation. Theory and Practices. Naphtali prints, Lagos. Nigeria ISBN: 978047686.

Rosengarten, F., (1984). The Book of Edible Nuts. $5^{\text {th }}$ Edn., Walker and Co., New York, USA., Pp:45.

Spore, R.G. (1997). More Cash Return from Cashew. CTA., The Nether Land, Pp: 4.

Topping, D.L, Stover, G.B, Calvert, G.D and Meller, R.D. (1980) Effect of Dietary

Saponins on fecal bile acids and natural sterols, plasma lipids and lipoprotein turnover in the pig. Am. J. Ani. Nutr. 1980; 33: 783-786.

Wade, and Stafford, (1968). The chemical analysis of foods. $7^{\text {th }}$ Edition. Churchill live store, p. 205-206.

Yusuf, A.A., Ayedun, H. and Sanni, L.O. (2008). Chemical composition and functional properties of raw and roasted Nigerian beeniseed (Sesamum Indicum) and Bambara groundnut (vigna subterranean) food chemical. 111 277-282. 